\title{
First records of Melanagromyza cuscutae Hering, 1958 (Diptera: Agromyzidae) from Slovakia and its new host plant
}

\author{
Peter Tóth, Miloš Černý \& Ludovít Cagáň
}

Tóth, P., Černý, M. \& Cagáň, L. 2004: First records of Melanagromyza cuscutae Hering, 1958 (Diptera: Agromyzidae) from Slovakia and its new host plant. Entomol. Fennica 15: 48-52.

The occurrence of Melanagromyza cuscutae Hering was observed in the agroecosystems of Slovakia. These findings were the first records of the species in Slovakia. Four dodder species were recorded at Slovakian cropland during the study. From those, Cuscuta europaea, C. lupuliformis and C. campestris served as hosts for $M$. cuscutae. There was no infestation of $C$. epithymum. Larvae fed within flower heads of $C$. europaea and $C$. lupuliformis but within the stems of C. campestris, where gall formation occurred. C. campestris was recorded as a host of $M$. cuscutae for the first time.

Peter Tóth, Slovak Agricultural University, Department of Plant Protection, A. Hlinku 2, 94976 Nitra, Slovak Republic; E-mail: petery@nextra.sk

Miloš Černý, 76363 Halenkovice 1, Czech Republic; E-mail: cerný.milos (a) centrum.cz

Ludovít Cagán̆, Slovak Agricultural University, Department of Plant Protection, A. Hlinku 2, 94976 Nitra, Slovak Republic; E-mail: ludovit.cagan@uniag.sk

Received 15 May 2003, accepted 12 September 2003

\section{Introduction}

Melanagromyza cuscutae Hering, 1958 was described for the first time in Germany (Hering 1958). The adult is entirely black, without any metallic coloration of the mesonotum or abdomen, the squama is whitish-grey with the margin and squamal fringe dark (Spencer 1973). Male genitalia were illustrated by Spencer (1962: Fig. 11, 1966: Fig. 19) and the larva by Hering (1958: 218). The genitalia of $M$. cuscutae (cf. Spencer 1966) are entirely typical of the genus and cannot be directly associated with the very similar species $M$. albocilia Hendel (also widespread in Slovakia, Tóth et al. 1998) feeding on Convolvulus (Spencer 1990). Although M. cuscutae ap- pears to occur primarily as a seed-feeder, it is also found in stems and the genitalia are typical of stem-boring species (Spencer 1966).

In Europe, M. cuscutae is only known to feed in seed-heads of Cuscuta europaea L., but in West Pakistan at Rawalpindi the larvae were found feeding exclusively in young stems of C. reflexa Roxb. (Spencer 1973). Elsewhere in the plains of West Pakistan, stems of other species of Cuscuta have been attacked, including C. approximata Babington, C. hyalina Roth and C. planiflora Tenore (Baloch et al. 1967). In India, it is known from stems and fruits of C. reflexa in Bihar (Sehgal 1965). In Kazakhstan, it feeds on the stems and fruits of $C$. europaea and C. lupuliformis (Ivannikov 1969). 
Host specificity tests showed that for normal maturation the female must be able to feed on Cuscuta sap oozing from punctures, which it makes with its ovipositor. Thus, M. cuscutae is believed to be highly host specific and therefore safe for use as a biocontrol agent (Baloch et al. 1967). The Pakistan and European populations have been observed attacking only dodders on shrubs and trees and not on field crops, which have thinner vines.

There are four species from Cuscutaceae known in Slovakian agroecosystems. They are Cuscuta epithymum L., C. europaea L., C. lupuliformis Krocker and C. campestris Yuncker (Tóth \& Cagán 2001). The objectives of this study were to determine the following: (1) presence of $M$. cuscutae in agroecosystems of Slovakia; (2) host range of M. cuscutae within the genus Cuscuta in Slovakia.

\section{Material and methods}

During the growing season 2001 the occurrence of $M$. cuscutae was observed irregularly in the agroecosystems of Slovakia following the natural phenology of dodders. Together 45 localities were chosen in different geographic and climatic regions throughout Slovakia. Collecting sites were Cuscuta spp. - infested croplands planted with various crops, fallow fields and roadsides. At each locality, plant species were identified.
Identification of Cuscuta spp. was based on the flower structure according to Dostál and Červenka (1992).

At each collecting site, Cuscuta plants were inspected for the presence of $M$. cuscutae larvae or pupae. The infested flower heads and stem galls were hand picked from the plants. The localities were inspected to record the presence of the M. cuscutae. Starting with a sample of 20 flower heads or stem galls per site, the number reached a maximum of 80 per site if less than three larvae or pupae were found from the first 20 flowerheads or stem galls.

To assess the adult emergence, field-collected flower heads or stem galls were placed in plastic tubes ( $8 \mathrm{~cm}$ diameter, $4.5 \mathrm{~cm}$ high) with perforated tops for aeration under laboratory conditions $\left(20^{\circ} \mathrm{C} \pm 1{ }^{\circ} \mathrm{C}\right)$. Emerged adults were identified.

\section{Results}

Melanagromyza cuscutae was found at 12 localities (Table 1). These findings are the first records of the species in Slovakia.

Of 300 Cuscuta spp. infested flowerheads and 100 stem galls collected during 2001 throughout Slovakia, 75 pupae were successfully reared to adult emergence (Table 2). The remaining larvae or pupae died before pupation and adult emergence respectively. The sex ratio of $\operatorname{recorded} M$.

Table 1. Details of localities where M. cuscutae was recorded.

\begin{tabular}{|c|c|c|c|c|}
\hline Locality & District $^{\mathrm{a}}$ & Altitude $(\mathrm{m})$ & Coordinates & Grid reference number ${ }^{\mathrm{b}}$ \\
\hline Biňovce & W & 198 & $48^{\circ} 30^{\prime} \mathrm{N} 17^{\circ} 29^{\prime} \mathrm{E}$ & 7470 \\
\hline Čoltovo & C & 227 & $48^{\circ} 30^{\prime} \mathrm{N} 20^{\circ} 23^{\prime} \mathrm{E}$ & 7588 \\
\hline Drieňov & $E$ & 226 & $48^{\circ} 52^{\prime} \mathrm{N} 21^{\circ} 16^{\prime} \mathrm{E}$ & 7193 \\
\hline Dubovec & $\mathrm{C}$ & 182 & $48^{\circ} 17^{\prime} \mathrm{N} 20^{\circ} 10^{\prime} \mathrm{E}$ & 7786 \\
\hline Hostie & W & 300 & $48^{\circ} 27^{\prime} \mathrm{N} 18^{\circ} 27^{\prime} \mathrm{E}$ & 7576 \\
\hline Koplotovce & W & 165 & $48^{\circ} 28^{\prime} \mathrm{N} 17^{\circ} 49^{\prime} \mathrm{E}$ & 7472 \\
\hline Machulince & W & 255 & $48^{\circ} 25^{\prime} \mathrm{N} 18^{\circ} 26^{\prime} \mathrm{E}$ & 7576 \\
\hline Mužla & W & 121 & $47^{\circ} 48^{\prime} \mathrm{N} 18^{\circ} 36^{\prime} \mathrm{E}$ & 8277 \\
\hline Nová Ves n/Žitavou & W & 164 & $48^{\circ} 17^{\prime} \mathrm{N} 18^{\circ} 20^{\prime} \mathrm{E}$ & 7775 \\
\hline Obyce & W & 250 & $48^{\circ} 26^{\prime} \mathrm{N} 18^{\circ} 27^{\prime} \mathrm{E}$ & 7576 \\
\hline Sikenica & W & 150 & $48^{\circ} 07^{\prime} \mathrm{N} 18^{\circ} 46^{\prime} \mathrm{E}$ & 7978 \\
\hline Želiezovce & W & 137 & $48^{\circ} 03^{\prime} \mathrm{N} 18^{\circ} 40^{\prime} \mathrm{E}$ & 7977 \\
\hline
\end{tabular}

a W - West Slovakia; E - East Slovakia; C - Central Slovakia.

${ }^{b}$ Grid reference number of the Databank of the fauna of Slovakia. 
Table 2. Host range of recorded $M$. cuscutae specimens in Slovakia.

\begin{tabular}{|c|c|c|c|c|c|}
\hline \multirow[t]{2}{*}{ Locality } & \multirow[t]{2}{*}{ Date } & \multirow[t]{2}{*}{ Cuscuta species } & \multirow[t]{2}{*}{ Cuscuta host plant } & \multicolumn{2}{|c|}{ Specimens reared } \\
\hline & & & & $\hat{\delta}$ & q \\
\hline Biňovce & 15.VIII.2001 & europaea & Urtica dioica & & 1 \\
\hline \multirow[t]{2}{*}{ Čoltovo } & 5.VII.2001 & lupuliformis & Rubus spp. & 1 & 1 \\
\hline & 8.VIII.2001 & lupuliformis & Rubus spp. & 24 & 26 \\
\hline Drieňov & 9.VIII.2001 & europaea & Urtica dioica, Calystegia sepium & 2 & \\
\hline Dubovec & 8.VIII.2001 & europaea & Robinia pseudoacacia & 2 & \\
\hline Hostie & 27.VIII.2001 & europaea & Urtica dioica, Rubus spp. & 2 & 4 \\
\hline Koplotovce & 15.VIII.2001 & europaea & Clematis spp., Rubus spp. & 1 & \\
\hline Machulince & 16.VIII.2001 & europaea & Urtica dioica, Rubus spp. & 1 & \\
\hline \multirow[t]{2}{*}{ Mužla } & 13.VI.2001 & campestris & Medicago sativa & 1 & 1 \\
\hline & 3.VII.2001 & campestris & Medicago sativa & 1 & \\
\hline Nová Ves n/Žitavou & 14.VIII.2001 & europaea & Urtica dioica, Rubus spp. & & 2 \\
\hline Obyce & 2.VIII.2001 & europaea & Urtica dioica, Rubus spp. & 2 & \\
\hline Sikenica & 8.VII.2001 & campestris & Medicago sativa & & 1 \\
\hline Zeliezovce & 22.VIII.2001 & campestris & Solanum tuberosum & 1 & 1 \\
\hline
\end{tabular}

Table 3. Wing span of recorded $M$. cuscutae specimens.

\begin{tabular}{|c|c|c|c|}
\hline \multirow[t]{2}{*}{ Locality } & \multirow[t]{2}{*}{ Date } & \multicolumn{2}{|c|}{ Wing span (mm) } \\
\hline & & $\delta$ & $q$ \\
\hline Biňovce & 15.VIII.2001 & & 2.53 \\
\hline \multirow[t]{2}{*}{ Čoltovo } & 5.VII.2001 & $2.00-2.52$ & $1.93-2.56$ \\
\hline & 8.VIII.2001 & 2.11 & 2.35 \\
\hline \multirow{2}{*}{ Drieňov } & 8.VIII.2001 & 2.28 & \\
\hline & 9.VIII.2001 & 2.46 & \\
\hline Dubovec & 8.VIII.2001 & $1.90-2.07$ & \\
\hline Hostie & 27.VIII.2001 & $2.32-2.46$ & $2.11-2.46$ \\
\hline Koplotovce & 15.VIII.2001 & 2.18 & \\
\hline Machulince & 16.VIII.2001 & 2.35 & \\
\hline \multirow[t]{2}{*}{ Mužla } & 13.VI.2001 & cannot be measured ${ }^{a}$ & cannot be measured $^{a}$ \\
\hline & 3.VII.2001 & 2.25 & \\
\hline Nová Ves n/Žitavou & 14.VIII.2001 & & $2.04-2.35$ \\
\hline Obyce & 2.VIII.2001 & $2.25-2.28$ & \\
\hline Sikenica & 8.VII.2001 & & 1.97 \\
\hline Zeliezovce & 22.VIII.2001 & 2.25 & 2.46 \\
\hline
\end{tabular}

cuscutae specimens was $1.00 \hat{\delta}: 1.03$ q . The wingspan within the specimens reared varied from $1.90-2.52 \mathrm{~mm}$ in males and from 1.93-2.56 $\mathrm{mm}$ in females (Table 3).

Four dodder species were recorded in Slovakian croplands. From those, only C. europaea, C. lupuliformis and $C$. campestris served as hosts for M. cuscutae (Table 2). During the study, there was no infestation of $C$. epithymum caused by $M$. cuscutae. C. epithymum was checked at 30 localities (alfalfa fields) throughout Slovakia. C. campestris was recorded as a host of $M$. cuscutae for the first time.

Larvae of $M$. cuscutae fed within flower heads of C. europaea and C. lupuliformis. A typical feeding pattern was the destruction of single seeds. The larvae destroyed most of the developing seeds within the flower head and pupated di- 
rectly on the base of the flower heads. On the other hand, flower heads of $C$. campestris were untouched by larvae. In the case of $C$. campestris, the larvae fed within the stem, where gall formation occurred. The larvae pupated directly within the galls.

\section{Discussion}

Although, M. cuscutae is only known to feed within seed-heads of $C$. europaea in Europe (Spencer 1990), our results showed the species also feeds within flower heads of $C$. lupuliformis and stems of $C$. campestris. The only Cuscuta species without $M$. cuscutae attack was $C$. epithymum in Slovakia. Even though we recorded M. cuscutae at 12 localities, it is possible to expect that the species is widespread in Slovakia as C. europaea and C. campestris were noticed throughout the country (Bertová 1988, Dostál \& Červenka 1992, Tóth \& Cagáň 2001). The most severe infestations by $M$. cuscutae within dodder plants were recorded on C. lupuliformis during the study (Table 2). The species was found only at one locality (Čoltovo), because it turns out to be more rare in Slovakia because of lack of suitable habitats (Tóth \& Cagáň 2001, Cagáň et al., 2001).

Volkov (1989) mentioned that the larvae of the 1st $M$. cuscutae generation mined in the stems, while those of the 2 nd destroyed the seeds of C. europaea and C. lupuliformis in Kazakhstan. However, we did not find infestation of stems in our study with the exception of the new host, C. campestris.

Spencer (1966) cited the wing length of $M$. cuscutae from $2.4 \mathrm{~mm}$ in males to 2.7 in females in European specimens and up to $2.8 \mathrm{~mm}$ in those from Pakistan (Spencer 1973). The wing span of Slovakian specimens varied only from 1.90-2.52 $\mathrm{mm}$ in males to $1.93-2.56 \mathrm{~mm}$ in females (Table 3 ). The presumable reason may be that Slovakia is on the northern border of its distribution. There are no records of the species from more northern countries (Spencer 1976).

Spencer (1965) stated: "When a species from family Agromyzidae is feeding on stems or seeds, there are a high degree of probability that the species will be strictly monophagous". In regard to M. cuscutae, this was confirmed by Baloch et al.
(1967) who carried out host specificity trials with plants from 36 different families. Single eggs were laid only on Tradescantia sp. (Commelinaceae) and Ipomoea batatas (Convolvulaceae). The eggs hatched but the larvae failed to develop.

We expect that $M$. cuscutae is a very promising biological control agent of Cuscuta spp., even if degree of parasitism should be carefully evaluated. This species is promising primarily because of its damage: the stem boring feeding causes gall formation on $C$. campestris and seed destruction of other Cuscuta spp. Especially important is its attack on invasive (within Europe) C. campestris. If the stem of the species is not attached to its host plant beyond the attacked (galled) part, the entire section is killed (Baloch et al. 1967). In addition, $M$. cuscutae can cause secondary damage, opening the door to several pathogens, such as fungi and bacteria, which can increase the ultimate damage and cause the death of the target plant.

Augmentation of M. cuscutae in Kazakhstan has been carried out by annual release of flies to overcome high winter mortality. For this purpose, infested plants were collected in autumn and held indoors over winter. In the spring the flies that emerged were released in the infested field (Ivannikov 1972). There have been no further published report on the use of $M$. cuscutae for biological control (CAB 1987), so it does not seem that the method was successful until now. To know more about its habit, life history and impact on host plants a detailed study will be required.

Acknowledgements. This work was supported by the Science and Technology Assistance Agency of Slovakia under the contract No. APVT-51-022002.

\section{References}

Baloch, G. M., Mohyuddin, A. I. \& Ghani, M. A. 1967: Biological control of Cuscuta sp. II. Biology and hostplant range of Melanagromyza cuscutae Hering (Dipt. Agromyzidae). - Entomophaga 12:481-489.

Bertová, L. (ed.) 1988. (Flora of Slovakia IV/4.) — Veda SAV, Bratislava. 570 pp. [In Slovak].

CAB International Institute of Biological Control. 1987: Digest: Potential for biological control of Cuscuta spp. and Orobanche spp. - Biocontrol News and Information 8: 193-199.

Cagáň, L., Komáromyová, E., Barta, M. \& Tóth, P. 2001: 
Cuscuta lupuliformis Krocker, (Cuscutaceae) - a new host for bean aphid, Aphis fabae Scopoli (Homoptera, Aphididae). - Acta Fytotechnica et Zootechnica 4: 84 .

Dostál, J. \& Červenka, M. 1992: (Determination tables for higher plants II.) - SPN, Bratislava. 784-1567. [In Slovak].

Hering, E. M. 1958: Melanagromyza cuscutae sp. n., eine neue fruchtfressende Agromyzide der Seide (Diptera, Agromyzidae). — Deutsche Entomologische Zeitschrift (NF) 5: 217-220.

Ivannikov, A. I. 1969: (The fly Melanagromyza cuscutae Hg. - an enemy of dodder in Kazakhstan.) - Vestnik Sel'skokhozyaistvennoi Nauki Kazakhstana 12: 8588. [In Russian].

Ivannikov, A. I. 1972: (The dodder fly.) — Zashchita Rastenii 17: 23-24. [In Russian].

Seghal, V. K. 1965: Studies on Indian Agromyzidae (Diptera). 2. - Beitr. Ent. 15: 3-10.

Spencer, K. A. 1962: Notes on the Oriental Agromyzidae (Diptera). 1. — Pacific Insects 4: 661-680.

Spencer, K. A. 1965: The species-host relationship in the Agromyzidae (Diptera) as an aid to taxonomy. - Proceedings of the XIIth International Congres of Ento- mology, 13 July, 1964, 101-102.

Spencer, K. A. 1966: A revision of European species of the genera Melanagromyza Hendel and Hexomyza Enderlein, with a supplement on the genus Ophiomyia Braschnikov. - Beitr Ent. 16: 3-60.

Spencer, K. A. 1973: Agromyzidae (Diptera) of Economic Importance. - Dr. W. Junk B. V., The Hague. 418 pp.

Spencer, K. A. 1976: The Agromyzidae (Diptera) of Fennoscandia and Denmark. Fauna Entomologica Scandinavica 5. - Scandinavian Science Press Ltd. Klampenborg, Denmark. 606 pp.

Spencer, K. A. 1990: Host Specialization in the World Agromyzidae (Diptera). - Kluwer Academic Publishers, London. 444 pp.

Tóth, P., Vráblová, M. \& Cagáň, L. 1998: First records of Melanagromyza albocilia (Agromyzidae, Diptera) from Slovakia. - Biologia, Bratislava 53: 604.

Tóth, P. \& Cagáň, L. 2001: Spread of dodder (Cuscuta spp.) in the agroecosystems of Slovakia: is it an emerging problem? - Acta Fytotechnica et Zootechnica 4: $117-120$.

Volkov, O. G. 1989: Prospects for biological regulation of Cuscuta. - Zashchita Rastenii 11: 18-19. 